\title{
Investigation of Power Quality Indices in Jordan University of Science and Technology Grid-Tie Photovoltaic Plant
}

\author{
MOHAMMED S. IBBINI and ABDULLAH H. ADAWI \\ DOI: https://doi.org/10.33976/JERT.7.2/2020/2
}

\begin{abstract}
In this paper, the effects of the grid-tie photovoltaic plant (PV) are analyzed on the power factor and the voltage harmonic distortion in the power quality aspect of the distribution network. The conditions for the total harmonic distortion (THD) in the power grid related to the photovoltaic power station connected to the user side are also summarized. Based on MATLAB/SIMSCAPE software, one string of the photovoltaic system at the Jordan University of Science and Technology (JUST) was simulated and hence, compared its results with the real results of the system. Measurement and simulation results illustrate that the voltage harmonic distortions to the power grid do not exceed the recommended levels, but the photovoltaic system needs to have a capacitor bank to get a unity power factor.
\end{abstract}

Index Terms - Power quality, Power factor, THD, Photovoltaic, PV Module, and MATLAB/SIMSCAPE.

\section{INTRODUCTION}

Photovoltaic is considered a promising technology, and it has witnessed rapid growth in recent years, especially after increasing the costs of fossil fuel. In the case of Jordan, shrinking resources and a reasonable energy crisis severely constrain economic prospects and industrial growth. Therefore, it is more urgent to increase the use of renewable energy.

Despite the great benefits that can be obtained from connecting the PV system with the power grid, new challenges on the grid designing and protection can emerge. Power flow direction and power quality (harmonics and voltage fluctuation) at the user side are affected after the PV system connected to the distribution network [1].

The energy extracted from the PV panel depends on various factors such as temperature, irradiance, and climate conditions. However, the sun irradiation strongly affects the performance of the power system due to continuous changes in the amount of radiation falling and leading to voltage flickering and fluctuation. The larger the capacity of the PV power system connected to the electrical grid, the higher the dynamic power quality problems resulting from photovoltaic power generation like frequency variation, voltage sag ...etc $[2,3]$.

Power systems designed to function at the fundamental frequency, which is $50-\mathrm{Hz}$ in Jordan, are prone to unsatisfactory operation and, at times, failure when subjected to voltages and currents that contain substantial harmonic frequency elements. Many problems can be caused by harmonics such as over-voltage, over-current, resonance, loss of transmission lines, and protection faults. Ensuring the voltage level and the power quality at the joint coupling point of the photovoltaic system is very important to achieve the best possible power system performance $[4$,
5].

In the Jordan University of Science and Technology (JUST) PV plant, SMA inverters are used due to the capability of providing reactive power and voltage adjustment. In many PV plants, the reactive power could be adjusted by external types of equipment like reactive power compensation systems, but it is better to use inverters that can adjust reactive power values [6].

If an immediate change in voltage happens, then this leads to the cause of what is known as a voltage flicker. Despite the voltage flicker usually happened at the user side, it affects the sinusoidal voltage waveform of the power grid. In the case of grid-tie PV plants, continuous changes in the amount of solar radiation leading to voltage flickering. Such distortions can disturb the user's equipment and cause the inrush current. Moreover, it affects the mechanism of the network impedance and leads to a sudden rise of voltage or sudden fall and hence, the causes of the voltage flicker [7].

The voltage flicker limits are contained in the following documents [8]:

(a) IEC/TR3 61000-3-7 (1996) “Assessment of emission limits for fluctuating loads in MV and HV power systems."

(b) IEC 868 / Engineering Recommendations P28 (pg 17) "Limits on voltage flicker short term and long-term severity values."

Harmonics are typically produced by the user's apparatus generating waveforms that distort the fundamental $50 \mathrm{~Hz}$ wave. Such harmonic generation can damage user apparatus and can fail transmission network apparatus. The limits for harmonic distortion levels are given in the following documents: 
(a) BS EN 50160:2000 "Voltage characteristics of electricity supplied by public distribution systems."

(b) UK Engineering Recommendation G5/4, February 2001 "Planning levels for harmonic voltage distortion and the connection of non-linear equipment to transmission systems and distribution networks."

(c) IEC/TR3 61000-3-6 (1996) "Assessment of emission limits for distorting loads in MV and HV power systems." All the requirements mentioned above and standards are essential for the power quality of the electrical grid, and there are always taken into account to ensure the energy quality of the Jordanian power system [9].

\section{PV SYSTEM MODELING}

The whole model of the PV system is built by MATLAB/SIMSACPE simulation software. The injection current, which comes from the photovoltaic generation system to the grid, could be transferred into essential components. The frequency of the inverter is the same as the power grid frequency, and its capacity is related to the output power of the PV system [10-12].

PV systems are like any other electrical power generation system, with only different components and hence, different physical properties. Although a PV array produces power when exposed to sunlight, several other components are required to conduct correctly, control, convert, distribute, and store the energy produced by the array. Depending on the functional and operational requirements of the system, the specific components required may include significant entities such as DC-AC power inverter, battery bank, etc.

The essential element of a PV module is called a PV cell. In SIMSCAPE workspace, a PV cell block can be used to precisely simulate the behavior of a real PV cell. More than one PV cell block can be used to make a PV module out of series and parallel connected cells. The module will have one input, irradiance in $\mathrm{W} / \mathrm{m}^{2}$, and two voltage polarity outputs, $+\mathrm{V}$ and $-\mathrm{V}$. The whole PV system, which consists of PV modules, MPPT controller, DC-DC converter and utility can be easily modeled using SIMSCAPE, as shown in Figure 1.

The adopted PV Cell specifications are as shown in Table1 below

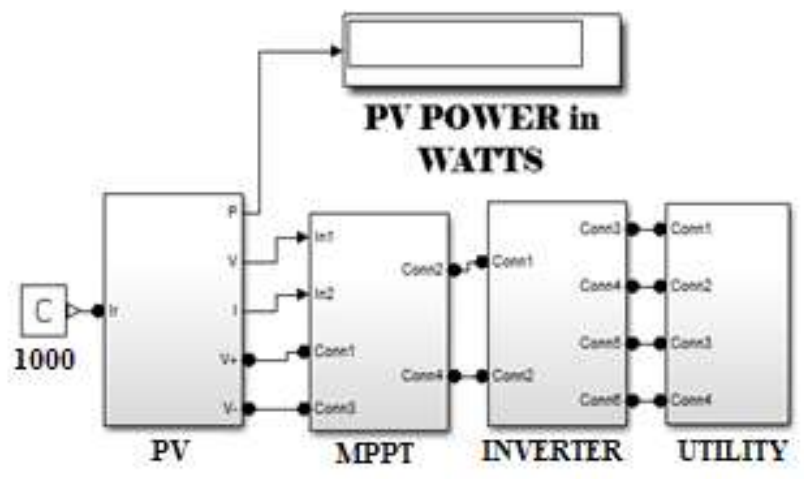

Fig. 1. MATLAB /SIMSCAPE model of the photovoltaic system.

TABLE 1

The PV Cell Specifications

\begin{tabular}{|l|l|}
\hline Number of PV module & 220 \\
\hline Number of PV module in series & 22 \\
\hline Open circuit voltage & $38.6 \mathrm{~V}$ \\
\hline Short circuit current & $9.03 \mathrm{~A}$ \\
\hline Voltage at MPP & $31.4 \mathrm{~V}$ \\
\hline Current at MPP & $8.44 \mathrm{~A}$ \\
\hline Maximum power & $265 \mathrm{~W}$ \\
\hline Number of inverters & 1 \\
\hline Inverter power & $60000 \mathrm{~W}$ \\
\hline
\end{tabular}

\section{CASE ANALYSIS}

At the JUST PV plant, one string is simulated in MATLAB/SIMSCAPE environment. Two hundred and twenty PV modules are connected, every 22 PV modules connected in series with total voltage about $850 \mathrm{VDC}$, these PV panels are combined in a DC combiner box. DC combiner box is directly connected to an SMA $60 \mathrm{KW}$ grid-tie inverter.

The following figures show the practical characteristics of the system during 2018, where the figures show the feasibility of installing such projects in Jordan. In Figure 2 , which shows the amount of solar radiation during the year, it is clear that the majority of the year has a very high level of solar radiation, which significantly increases the efficiency of the system and reduces the cost of project recovery. 


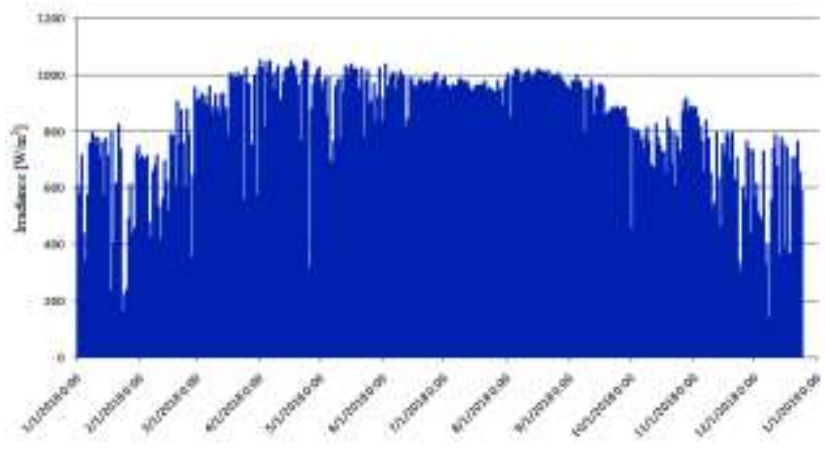

Fig. 2. Irradiation in JUST PV plant during the year 2018

The following tables show the differences between simulation and actual results in the same operating conditions.

The proposed simulation performance is tested under two conditions, the first condition at $1000 \mathrm{~W} / \mathrm{m}^{2}$ solar radiation and temperature of $17.94 \mathrm{C}^{\circ}$, the second condition at $615 \mathrm{~W} / \mathrm{m}^{2} \mathrm{so}-$ lar radiation, and temperature of $16.86 \mathrm{C}^{\circ}$. According to the following results, it's evident that the simulation results are very close to the real readings of the photovoltaic system at the same operating conditions.

TABLE 2

Differences between simulation results and actual results at $1000 \mathrm{~W} / \mathrm{m}^{2}, 17.94 \mathrm{C}^{\circ}$

\begin{tabular}{|c|c|c|}
\hline Irradiance & $\begin{array}{c}\text { Real system } \\
\text { results }\end{array}$ & $\begin{array}{c}\text { Simulation } \\
\text { results }\end{array}$ \\
\hline Temperature & $1000 \mathrm{~W} / \mathrm{m}^{2}$ & $1000 \mathrm{~W} / \mathrm{m}^{2}$ \\
\hline $\begin{array}{c}\text { Maximum DC } \\
\text { Power }\end{array}$ & $50.04 \mathrm{KW}$ & $17.94 \mathrm{C}^{0}$ \\
\hline $\begin{array}{c}\text { Maximum DC } \\
\text { Voltage }\end{array}$ & $619.4 \mathrm{~V}$ & $69.30 \mathrm{KW}$ \\
\hline Active Power & $47.69 \mathrm{KW}$ & $58.30 \mathrm{KW}$ \\
\hline Power Factor & 0.93 & 1 \\
\hline $\begin{array}{c}\text { Maximum AC } \\
\text { current L1 }\end{array}$ & $74.7 \mathrm{~A}$ & $84.49 \mathrm{~A}$ \\
\hline $\begin{array}{c}\text { Maximum AC } \\
\text { current L2 }\end{array}$ & $74.8 \mathrm{~A}$ & $84.49 \mathrm{~A}$ \\
\hline $\begin{array}{c}\text { Maximum AC } \\
\text { current L3 }\end{array}$ & $74.6 \mathrm{~A}$ & $84.49 \mathrm{~A}$ \\
\hline $\begin{array}{c}\text { Maximum AC } \\
\text { voltage L1 }\end{array}$ & $242.95 \mathrm{~V}$ & $230 \mathrm{~V}$ \\
\hline $\begin{array}{c}\text { Maximum AC } \\
\text { voltage L2 }\end{array}$ & $240.57 \mathrm{~V}$ & $230 \mathrm{~V}$ \\
\hline $\begin{array}{c}\text { Maximum AC } \\
\text { voltage L3 }\end{array}$ & $240.23 \mathrm{~V}$ & $230 \mathrm{~V}$ \\
\hline
\end{tabular}

TABLE 3

Differences between simulation results and actual results at $615 \mathrm{~W} / \mathrm{m}^{2}, 16.86 \mathrm{C}^{\circ}$

\begin{tabular}{|l|c|c|}
\hline & $\begin{array}{c}\text { Real sys- } \\
\text { tem results }\end{array}$ & $\begin{array}{c}\text { Simulation } \\
\text { results }\end{array}$ \\
\hline Irradiance & $615 \mathrm{~W} / \mathrm{m}^{2}$ & $615 \mathrm{~W} / \mathrm{m}^{2}$ \\
\hline Temperature & $16.86 \mathrm{C}^{\mathrm{o}}$ & $16.86 \mathrm{C}^{\mathrm{o}}$ \\
\hline $\begin{array}{l}\text { Maximum DC } \\
\text { Power }\end{array}$ & $30.95 \mathrm{KW}$ & $36.80 \mathrm{KW}$ \\
\hline $\begin{array}{l}\text { Maximum DC } \\
\text { Voltage }\end{array}$ & $640.8 \mathrm{~V}$ & $400 \mathrm{~V}$ \\
\hline Active Power & $30.47 \mathrm{KW}$ & $36.80 \mathrm{KW}$ \\
\hline Power Factor & 0.92 & 1 \\
\hline $\begin{array}{l}\text { Maximum AC } \\
\text { current L1 }\end{array}$ & $46.5 \mathrm{~A}$ & $53.30 \mathrm{~A}$ \\
\hline $\begin{array}{l}\text { Maximum AC } \\
\text { current L2 }\end{array}$ & $46.6 \mathrm{~A}$ & $53.30 \mathrm{~A}$ \\
\hline $\begin{array}{l}\text { Maximum AC } \\
\text { current L3 }\end{array}$ & $46.5 \mathrm{~A}$ & $53.30 \mathrm{~A}$ \\
\hline $\begin{array}{l}\text { Maximum AC } \\
\text { voltage L1 }\end{array}$ & $239.04 \mathrm{~V}$ & $230 \mathrm{~V}$ \\
\hline $\begin{array}{l}\text { Maximum AC } \\
\text { voltage L2 }\end{array}$ & $236.74 \mathrm{~V}$ & $230 \mathrm{~V}$ \\
\hline $\begin{array}{l}\text { Maximum AC } \\
\text { voltage L3 }\end{array}$ & $236.17 \mathrm{~V}$ & $230 \mathrm{~V}$ \\
\hline
\end{tabular}

These values in the tables show the differences between the real values of the solar system and the simulation values when modeling the solar system through a MATLAB/SIMSCAPE program. Many values, such as the value of solar radiation and temperature are assumed to be constant. However, these values are constantly changing, resulting in differences between actual values and simulation values. Another reason may strongly affect the difference in readings between actual and simulated values, which is partial shading. In the case of partial shading, the actual power values of the PV system less than the simulation values. The simulation programs cannot consider the impact of all operating conditions, but it is clear that its results are very close to the actual values and this indicates the strength of the simulation program.

THD in the output voltage is illustrated in Figure 3. 


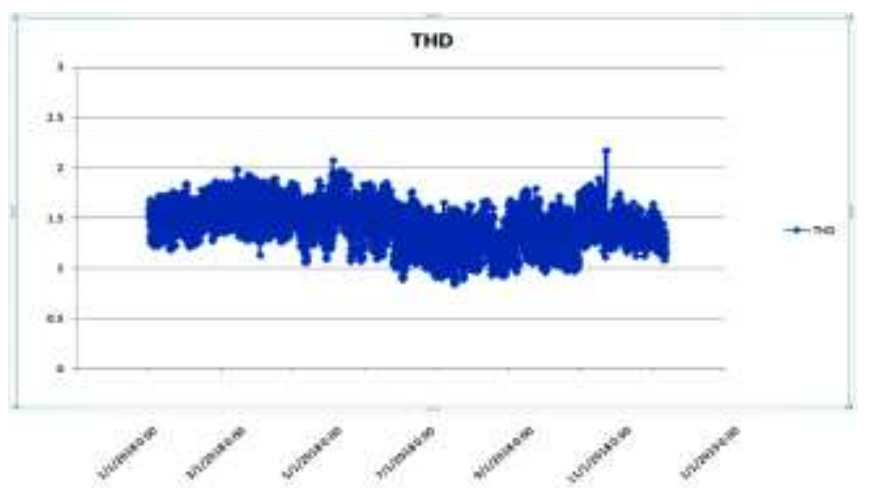

Fig. 3. THD in the output voltage.

It's evident from the previous figure that the THD over a whole year was very few and within the recommended levels in international standards rules. On the other hand, the simulation result illustrates that the THD $=0.02$, MATLAB/SIMSCAPE software, provides an FFT command window. This command window is used to make many analysis features like THD.

The terms of calculation and assessment of the reactive power of the grid-tie PV systems are [13]:

1) The voltage levels of the electrical grid must remain stable and within normal range with PV power generation.

2) The reactive power exchange between $P V$ generation and grid on the point of common coupling is zero.

As mentioned previously, the inverters used in the PV power system are of type SMA; this type can compensate for the reactive power values. Moreover, it is allowing the power factor values to stay within the normal range. The following picture illustrates the power factor values during 2018.

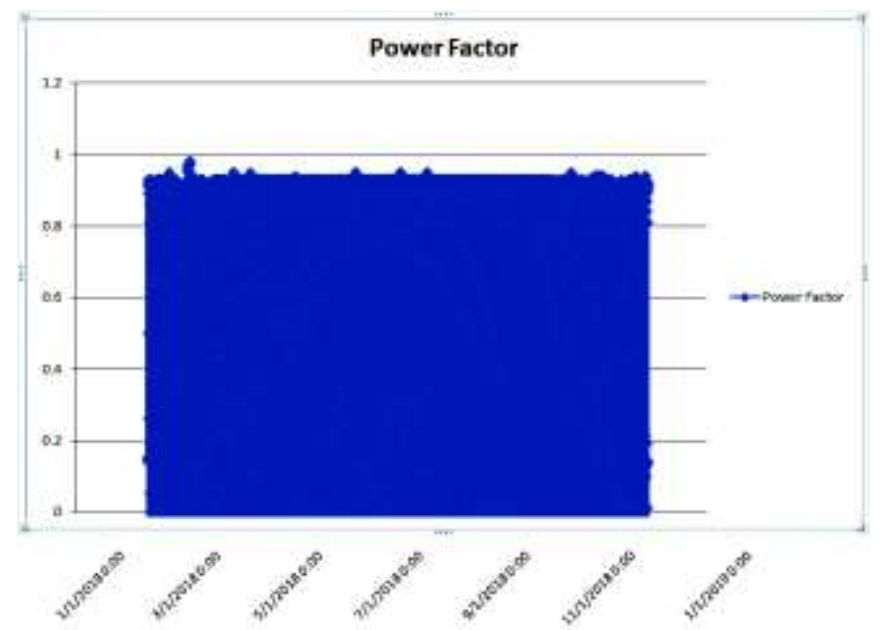

Fig. 4. Power factor values in 2018.
It's evident from the previous figure that the power factor of the grid-tie photoelectric system is equal to 0.9 at most times and this is considered very well. To access a unity power factor using MATLAB/SIMSCAPE software. The values in Tables 2 and 3 are taken into account. Moreover, the power factor correction is:

$k V A r=$ Power $(K W)\left(\operatorname{Tan}\left(\emptyset_{A}-\emptyset_{B}\right)\right)$,

Where,

$\emptyset_{A}=\cos ^{-1}$ ( initial power factor )

$\emptyset_{B}=\cos ^{-1}$ ( required power factor )

According to Table $3, \emptyset_{A}=\cos ^{-1}(0.92)$, and the required power factor is 1 . However, the active power is $30.47 \mathrm{KW}$, so regarding the previous equation, the capacitor bank should be added with a capacity of 20kVAR per string. The following figure illustrates the value of the power factor after the addition of the capacitor bank.

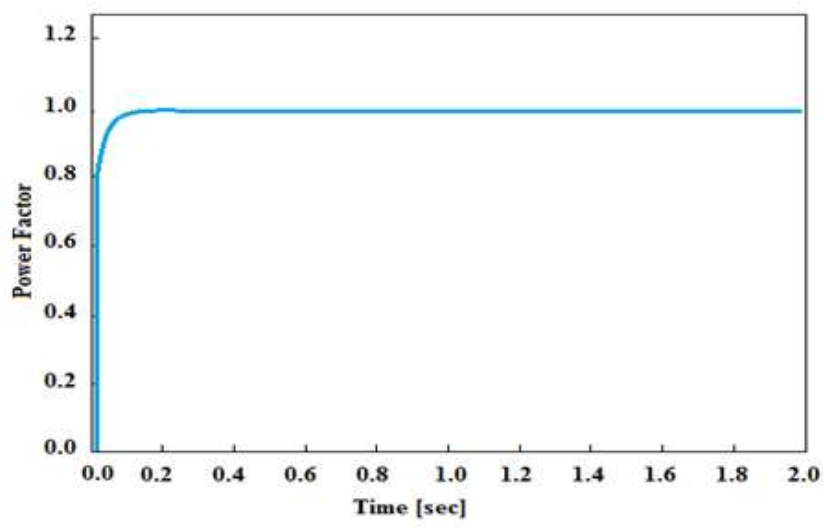

Fig. 5. Power factor simulation result after the addition of compensator.

\section{CONCLUSION}

In this paper, the impact of the grid-tie photovoltaic power system in JUST and the power quality in the distribution network was analyzed and studied. The power quality problems resulting from connecting the photovoltaic power plant to the electrical grid were summarized, and quality standards and requirements for maintaining power quality were mentioned.

Based on the MATLAB/SIMSCAPE simulation software, this paper simulates the THD and power factor in the case of Jordan University of science and technology grid-tie photovoltaic plant.

The result illustrated that

1) The THD caused by grid-tie photovoltaic plant injecting into the grid satisfies standards requirements.

2) 20KVAR capacitor bank capability per string should be added to the photovoltaic system to obtain a unity power factor.

It is also recommended to study the effect of voltage fluctuation, voltage flickering, and other factors that impact the quality of electrical power. 


\section{REFERENCES}

[1] K. Thirumala, T. Jain, and A. C. Umarikar, "Visualizing time-varying power quality indices using generalized empirical wavelet transform," Electr. Power Syst. Res., vol. 143, 2017.

[2] S. Yan, S.-C. Tan, C. K. Lee, B. Chaudhuri, and S. Y. Hui, "Use of Smart Loads for Power Quality Improvement," IEEE J. Emerg. Sel. Top. Power Electron., vol. 6777, no. c, 2016.

[3] H. Al Riyami, A. Al Busaidi, A. Al Nadabi, M. Al Siyabi, O. H. Abdalla, K. Al Manthari, B. Hagenkort, S. Mirza, and R. Fahmi, "Power Quality of Dhofar Network with 50 MW Wind Farm Connection," 2016.

[4] B. Stridh and J. Rosenlind, "Power quality experiences from Sweden â€TM s first MW photovoltaics park and impact on LV planning," 2016.

[5] S. Jo, S. Son, and J. Park, "On Improving Distortion Power Quality Index in Distributed Power Grids," vol. 4, no. 1, pp. 586-595, 2013.

[6] N. Mu, J. C. Alfonso-gil, S. Orts-grau, S. Seguí-chilet, and F. J. Gimeno-sales, "Instantaneous approach to IEEE .power terms and quality indices," vol. 125, 2015.

[7] J. Barros and R. I. Diego, "A review of measurement and analysis of electric power quality on shipboard power system networks," Renew. Sustain. Energy Rev, vol. 62, 2016.

[8] D. D. Ferreira, J. M. De Seixas, A. S. Cerqueira, C. A. Duque, M. H. J. Bollen, and P. F. Ribeiro, "A new power quality deviation index based on principal curves," Electr. Power Syst. Res., vol. 125, 2015.

[9] E. Almaita, "Harmonic Assessment in Jordanian Power Grid Based on Load Type Classification," vol. 11, 2016.

[10] M. S. Ibbini, A. H. Adawi, "A Simscape Based Design of a Global Maximum Power Point Tracker under Partial Shading Condition", International Journal of Smart Grid and Clean Energy, vol. 8, no. 1, January 2019.

[11] M. S. Ibbini, A. H. Adawi, "Analysis and Design of a Maximum Power Point Tracker for a Stand-Alone Photo Voltaic System Using Simscape", International Journal of Advanced Trends in Computer Science and Engineering, vol. 8, no. 1, January - February 2019.

[12] M. S. Ibbini, A. H. Adawi, "A SIMSCAPE Based Design of a Dual Maximum Power Point Tracker of a StandAlone Photovoltaic System." International Journal of Electrical and Computer Engineering (IJECE), vol. 10, no. 3, June 2020.

[13] C. M. De Brito, P. Van Rhyn, and S. Africa, "The Use of Power Quality Standards to Establish an Equivalent Transformer Capability Under Harmonic Loading," 2016.

Mohammed Salameh Ibbini received his Ph. D in electrical engineering from the University of Illinois at Urbana-Champaign, his M. SC. in electrical engineering from the University of Coloradoat
Boulder and his B. Sc. in Electronics from the ENSEEC in France. $\mathrm{He}$ is currently Professor of electrical and biomedical engineering at Jordan University of Science \& Technology. He is currently the vice president of Jordan University of Science and Technology and had held different administrative and academic positions. Mohammed Ibbini has been professor of EE and BME at JUST since 2005, authoring and co-authoring over 70 articles and attending a huge number of international conferences. Professor Ibbini taught different courses in linear and nonlinear control, biomedical instrumentation, signal and systems and machines. His research interest includes but not limited to nonlinear control, renewable energy, feedback linearization, ultrasound and microwave cancer therapy, diabetes and bridging the gap between the university output and the work market needs. Prof. Ibbini is a strong advocate of hands-on, real life examples, project based learning, learning by doing and innovation in Engineering.

Abdullah Hamed Adawi is born in Saudia Arabia In 1990, I obtained a bachelor degree in Electrical Power Engineering in 2012 from Albalqaa Applied University. I received my Master in 2019 in the field of Power and Control Engineering from Jordan University of Science and Technology. 